\title{
RÓŻNICE WE WDRAŻANIU BUSINESS PROCESS REENGINEERINGU W ORGANIZACJACH PUBLICZNYCH I BIZNESOWYCH
}

Z a r y s t r e ś c i: Rozwój zainteresowania koncepcjami opartymi na procesach jako narzędziem poprawiającym efektywność organizacji wynikał z krytyki podejścia funkcjonalnego w organizacji. W artykule przedstawiono koncepcję business process reengineering. Celem niniejszego opracowania jest określenie różnic oraz czynników sukcesu we wdrażaniu tej koncepcji w organizacjach publicznych i biznesowych. Istotnym obszarem różniącym podejście do wdrażania BPR w analizowanych organizacjach jest oczekiwanie, co do efektów jego zastosowania, znaczenia wpływu otoczenia oraz różne rozumienie znaczenia odbiorcy usług.

$\mathrm{S} \nmid$ o w a $\mathrm{k} 1 \mathrm{u} \mathrm{c} \mathrm{z} \mathrm{o} \mathrm{w} \mathrm{e:} \mathrm{business} \mathrm{process} \mathrm{reengineering,} \mathrm{organizacja} \mathrm{publiczna,}$ organizacja biznesowa.

K l a s y fik a c j a J E L: L32.

\section{WSTĘP}

Podejście oparte na procesach w zarządzaniu wykorzystywane jest zarówno w organizacjach biznesowych, jak również publicznych. Podstawowym założeniem podejścia procesowego jest optymalizacja funkcjonowania

* Adres do korespondencji: Uniwersytet Warmińsko-Mazurski w Olsztynie, Wydział Nauk Ekonomicznych, Katedra Organizacji i Zarządzania, ul. M. Oczapowskiego 4, 10-719 Olsztyn, e-mail: krzysztof.krukowski@uwm.edu.pl. 
oparta na procesie. W ujęciu prakseologicznym T. Pszczołkowski zdefiniował proces jako splot lub pasmo zdarzeń permutacyjnych przebiegających w czasie, ujmowane jako całość ze względu na jakieś wyróżnione cechy [Pszczołkowski 1978, s. 185]. Jedną z bardziej popularnych definicji procesu przedstawili M. Hammer i J. Champy. Według tych autorów proces to wiązka aktywności organizacji skierowana na jedno lub kilka wejść, w wyniku której odbiorca otrzymuje produkt (usługę) o pożądanej przez niego wartości [Hammer, Champy 1996, s. 17]. Rozwój zainteresowania procesami jako narzędziem poprawiającym efektywność organizacji wynikał z krytyki podejścia funkcjonalnego, opierającego się na pionowych strukturach organizacyjnych. Jedną z przyczyn krytyki organizacji zbudowanych pionowo jest ich wysoki poziom zbiurokratyzowania. W przypadku coraz bardziej skomplikowanych procesów produkcyjnych doprowadziło to do zmniejszenia sprawności funkcjonowania organizacji biznesowych. Między innymi dlatego też podejście procesowe wydaje się czynnikiem decydującym w dużej mierze o efektywności organizacji [Grajewski 2007, s. 54]. W praktyce i teorii organizacji biznesowych znajduje się wiele rozwiązań, które oparte są na procesach. Jednym z nich jest koncepcja business process reengineeringu (BPR). Podejście procesowe wykorzystywane jest również między innymi w koncepcji (TQM - Total Quality Management), zarządzaniu wiedzą, lean managemantu, kaizen, benchmarkingu oraz outsourcingu.

W organizacjach biznesowych zastosowano tę koncepcję w podmiotach które były zbiurokratyzowane oraz posiadały struktury funkcjonalne. Takimi cechami charakteryzują się obecnie funkcjonując organizacje publiczne. Są one tradycyjnie silnie zbiurokratyzowane, a podstawową strukturą, która w nich występuje jest struktura organizacyjna funkcjonalna. Dlatego też zastosowanie BPR w organizacjach publicznych może być jednym z podstawowych narzędzi ich doskonalenia.

Celem niniejszego opracowania jest określenie różnic we wdrażaniu koncepcji BPR w organizacjach publicznych i biznesowych oraz określenie kluczowych czynników w jej wdrażaniu.

\section{RÓŻNICE POMIĘDZY ORGANIZACJĄ PUBLICZNĄ A BIZNESOWA}

Definiując pojęcie organizacji można się oprzeć na podejściu prakseologicznym, według którego ma ono trzy znaczenia przedmiotowe (pewien 
obiekt, który posiada cechy charakterystyczne odróżniające go od innych), czynnościowe (,tworzenie” organizacji w ujęciu rzeczowym) oraz atrybutowe (organizacja jest cechą przedmiotów złożonych, czyli jest zorganizowana) [Pszczołkowski 1978, s. 150-151]. Na tym gruncie można określić pewne różnice, które odróżniają organizację publiczną od biznesowej w ujęciu przedmiotowym. Do wskazania różnic pomiędzy nimi można posłużyć różnymi obszarami. Należą do nich czynniki otoczenia, transakcje z otoczeniem oraz procesy i struktura wewnętrzna [Rainey i in. 1976, s. 236-237]. Czynnikami otoczenia jest to wszystko, co występuje poza organizacją, a ma na nią wpływ. Wymienić w tym obszarze można wpływ działania rynku, który w przypadku organizacji biznesowych jest jednoznaczny, warunkuje odniesienie sukcesu i jest źródłem zasobów, informacji oraz ograniczeń. W przypadku organizacji publicznych rynek nie jest traktowany jako źródło dochodów, nie dostarcza zachęt do redukcji kosztów, efektywnego i skutecznego działania. Mniejszy wpływ rozwiązań rynkowych powoduje również, że organizacje publiczne w swym działaniu nie muszą odzwierciedlać preferencji klientów, jak również nie muszą obserwować relacji pomiędzy popytem a podażą na swoje usługi. W przypadku organizacji publicznych nie występuje również monitorowanie wskaźników rynkowych np. ceny, kosztów. Drugim obszarem w przypadku czynników otoczenia są ograniczenia prawne. Wielu autorów, aby wskazać różnice pomiędzy typami organizacji koncentruje się na wpływie prawa, instytucji rządowych wpływających na niezależność i elastyczność funkcjonowania organizacji. Wpływ ten w organizacjach publicznych jest większy. Menadżerowie tych organizacji mają więcej ograniczeń proceduralnych oraz co bardzo istotne - nie mają pełnej autonomii w wyborze sfery działalności. Mają oni również skłonność do większej formalizacji swoich działań. Warunki prawne powodują również więcej zewnętrznych źródeł formalnego wpływu na organizację publiczną. Bardzo istotnym czynnikiem w obszarze czynników zewnętrznych jest wpływ polityki na zarządzanie organizacją publiczną. Charakteryzuje się one poprzez większą różnorodność i intensywność nieformalnych wpływów zewnętrznych na decyzje menadżerów niż w organizacjach biznesowych. Menadżerowie organizacji publicznych muszą również zabiegać o poparcie wyborców, którzy mogą mieć wpływ na procesy decyzyjne.

Drugim obszarem, który można brać pod uwagę do odróżnienia specyfiki organizacji publicznej i organizacji biznesowej, jest specyfika transakcji z otoczeniem. Jednym z podstawowych czynników z tego wynikających jest $\mathrm{w}$ wielu przypadkach przymusowy lub monopolistyczny charakter 
usług świadczonych przez organizacje publiczne. Odbiorcy usług świadczonych przez organizacje publiczne mają tendencję do zachowywania się jak ,free riders" i wychodzą z założenia, że będą korzystać z usług, ale niech inni za nich płacą. Rząd wykorzystuje zatem wpływy z podatków na rzecz zaspokojenia tych potrzeb np. bezpieczeństwo publiczne, obronna narodowa [Rainey 2009, s. 89]. Z drugiej strony rząd ma narzędzia przymusu, aby obywatele korzystali z jego usług np. obowiązek rejestracji pojazdu. Kluczowymi aspektami rozróżnienia w tym obszarze jest przede wszystkim fakt, że interesy publiczne różnią się od prywatnych, ponieważ organizacje sektora publicznego muszą rozważyć szerszy zbiór norm i wartości w procesie świadczenia usług [Christensen i in. 2007, s. 4]. W tym obszarze należy również zwrócić uwagę na kontrolę publiczną, która w przypadku organizacji publicznych i ich menadżerów jest dużo szersza. Specyfika relacji z otoczeniem wynika również z faktu, że menadżerowie organizacji publicznych muszą sprostać unikalnym oczekiwaniom społeczeństwa. Opinia publiczna wymaga od nich działania charakteryzującego się sprawiedliwością, wrażliwością, odpowiedzialnością oraz uczciwością.

Trzeci obszar, na podstawie którego można przedstawić różnice dotyczy struktury i procesów wewnętrznych. Podział czynników dotyczących relacji wewnętrznych przedstawili H.G. Rainey, R.W. Backoff, Ch.H. Levine [Rainey 1976, s. 236-237] (tabela 1). Wskazali oni pięć obszarów:

1. Złożoność procesu decyzyjnego.

2. Role kierownicze.

3. Wydajność organizacji.

4. Narzędzia motywowania.

5. Cechy osobowe pracowników.

W ramach tego obszaru można brać pod uwagę różne czynniki. B. Kożuch, przedstawiając główne różnice pomiędzy organizacjami sektora publicznego i prywatnego, wzięła pod uwagę planowanie i wyznaczanie celów, organizowanie, przewodzenie i kontrolę [Kożuch 2006, s. 51-52].

Biorąc pod uwagę różne kryteria odróżniające organizacje publiczne od biznesowych należy pamiętać, że posiadają one również cechy, które są charakterystyczne dla innych organizacji, takie jak: posiadanie specyficznego celu lub celów, który organizacja pragnie osiągnąć; ludzie, jako składniki organizacji oraz strukturę organizacyjną. 
Tabela 1. Specyfika relacji wewnętrznych organizacji publicznych

\begin{tabular}{|l|l|}
\hline \multicolumn{1}{|c|}{ Obszar } & \multicolumn{1}{c|}{ Kryteria } \\
\hline $\begin{array}{l}\text { Złożoność procesu } \\
\text { decyzyjnego wyboru } \\
\text { celów }\end{array}$ & $\begin{array}{l}\text { Większa ilość i różnorodność celów i kryteriów ich wyboru. } \\
\text { Większa nieokreśloność i niematerialność celów i kryteriów } \\
\text { wybory } \\
\text { Większa skłonność do formułowania sprzecznych celów } \\
\text { (więcej „kompromisów”). }\end{array}$ \\
\hline Role kierownicze & $\begin{array}{l}\text { Mniejsza autonomia podejmowania decyzji i ich elastyczność. } \\
\text { Słabsza, bardziej podzielona władza nad podwładnymi na } \\
\text { niższych poziomach organizacji. } \\
\text { Większa niechęć do delegowania uprawnień. Więcej pozio- } \\
\text { mów kontroli i większe wykorzystanie formalnych regulacji. } \\
\text { Większy wpływ polityki na pracowników. }\end{array}$ \\
\hline Wydajność organizacji & $\begin{array}{l}\text { Większa ostrożność, sztywność funkcjonowania. } \\
\text { Mniejsza innowacyjność. } \\
\text { Częstsze zmiany menadżerów z powodu wyborów i politycz- } \\
\text { nych mianowań skutkuje większymi zakłóceniami w realizacji } \\
\text { planów }\end{array}$ \\
\hline Narzędzia motywowania & $\begin{array}{l}\text { Większe trudności w tworzeniu zachęt do efektywnego i sku- } \\
\text { tecznego działania. } \\
\text { Niższa wartość zachęt pieniężnych dla pracowników. }\end{array}$ \\
\hline Cechy osobowe pracow- & $\begin{array}{l}\text { Mniejsze zadowolenie z pracy. } \\
\text { Mniejsze zaangażowanie organizacyjne. } \\
\text { Motywatorem do pracy są względy ideowe. }\end{array}$ \\
\hline
\end{tabular}

Źródło: opracowanie własne na podstawie H.G. Rainey, R.W. Backoff, Ch. H. Levine, Comparing Public and Private Organizations. Public Administration Review, Vol. 36, No. 2 (Mar.-Apr., 1976), p. 236-237.

\section{BUSINESS PROCESS REENGINEERING W RÓŻNYCH TYPACH ORGANZIACJI}

Re-engineering został zdefiniowany przez M. Hammera, J. Champy jako fundamentalne przemyślenie i drastyczne przeprojektowanie procesów biznesowych w celu osiągnięcia radykalnej poprawy w funkcjonowaniu organizacji [Hammer, Champy 1993, s. 46]. Według R. Gabryelczyk jest to „koncepcja zmian, prowadzącą do systematycznej organizacji oraz analizy i oceny procesów gospodarczych, dodających wartość z punktu widzenia klienta, w celu uzyskania poprawy miar, takich jak czas, koszt i jakość pro- 
cesów" [Gabryelczyk 2000, s. 22]. Wśród wielu zalet wprowadzenia metody opartej na doskonaleniu organizacji opartej procesach wymienia się: poprawę jakości projektu i skrócenie czasu jego opracowania, redukcję zatrudnienia pracowników, poprawę wyników finansowych, skrócenie czasu przekazywania informacji wewnątrz organizacji, jak i poza nią, udoskonalenie systemu obsługi klientów oraz eliminację niepotrzebnych czynności [Kisielnicki 2008, s. 185]. Kluczowe czynniki są grupą kryteriów (kompetencji, zasoby, sił), które uważamy za najważniejsze w procesie wdrażania danej inicjatywy w organizacji.

Wśród wielu badań nad identyfikacją kluczowych czynników sukcesu we wprowadzaniu BPR w organizacjach publicznych i prywatnych należy zwrócić uwagę na badania przeprowadzone przez McAdama i O'Hare [McAdam O’Hare 1998, s. 226-240]. Ich badania dotyczyły wdrożenia BPR w sektorze publicznym oraz określenia czynników sukcesu w ich realizacji. Badania obejmowały również sprawdzenie czy czynniki sukcesu w organizacjach biznesowych są takie same jak w organizacjach publicznych. Wyniki badań wykazały, że takie czynniki, jak: zaangażowanie najwyższego kierownictwa, zaangażowanie pracowników, skuteczna komunikacja oraz praca zespołowa są kluczowymi czynnikami we wdrażaniu podejścia procesowego w sektorze publicznym. Czynnikiem wyróżniającym sektor publiczny jest wpływ polityki (polityków), a pozostałe czynniki wdrażania BPR realizowane są jak w sektorze prywatnym.

W przypadku organizacji biznesowych czynniki sukcesu wdrażania BPR dotyczą [Brilman 2002, s. 275-276; Oliński 2013, s. 230-231]:

- Zaangażowania kadry zarządzającej. Zaangażowanie powinno wyrażać się poprzez permanentne śledzenie realizacji projektu i częste komunikowanie się naczelnego kierownictwa z pracownikami oraz mianowanie osoby odpowiedzialnej za realizację BPR, podlegającej bezpośrednio w tej sprawie naczelnemu kierownictwu.

- Ukierunkowania procesów na klienta. Projektowanie kluczowych procesów w przedsiębiorstwie biorąc pod uwagę ostatecznego klienta.

- Określenia ambitnych celów. Związane jest to z zakładaną w tej metodzie BPR ,radykalną” poprawą.

- Powoływania zespołów wielodyscyplinarnych.

- Umożliwienia kreatywności. Najbardziej prowokujące pomysły powinny być brane pod uwagę. Jeśli któryś z nich został odrzucony to dlatego, że okazał się nieefektywny ekonomicznie, ale nigdy nie powinien być odrzucony z powodu jego nadmiernej śmiałości. 
- Włączania informatyków w pracę zespołu.

- Właściwego doboru pierwszych działań. Zaczynać się powinno od zmiany procesów uznanych za szczególnie ważne dla przedsiębiorstwa.

Do kluczowych czynników sukcesu wdrażania BPR w organizacjach biznesowych zalicza się również zdolności komunikacyjne naczelnego kierownictwa, edukację i trening pracowników, opracowanie projektu wprowadzenia BPR, pracę zespołową; wsparcie informacyjno-technologiczne oraz współpracę pracowników [Herzog, i in. 2007, s. 5811-5834].

Na podstawie literatury można zidentyfikować czynniki, które utrudniają wdrożenie BPR w organizacjach biznesowych. Można je potraktować jako kluczowe do ich realizacji w przypadku minimalizacji ich skutków. Należą do nich [Habib 2013, s. 4]:

1. Heterogeniczność zarządzania. BPR wymaga koordynacji pracowników, procesów i technologii, ale może to być osiągnięte tylko poprzez posiadanie wizji i wartości przez kierownictwo organizacji. Najwyższe kierownictwo czasem jest mało elastyczne w tym zakresie i nie wprowadza harmonii i integracji w kluczowych komponentach (pracownicy, procesy, technologia).

2. Niejasna metodologia. Dostosowanie odpowiedniej metodologii jest niezbędne dla powodzenia procesu radykalnych zmian, ale przedsiębiorstwa przyjmując BPR często nie wybierają właściwej metodyki wprowadzania zmian.

3. Zaangażowanie pracowników i bezpieczeństwo zatrudnienia. Naczelne kierownictwo zapomina, aby zapewnić bezpieczeństwo pracy, może mieć to wpływ na niskie morale i zaangażowanie pracowników w procesie zmian.

4. Skupienie się na celach krótkoterminowych. BPR jest procesem długotrwałym ze względu na zmiany trwałe i trwa znacznie w rozwoju.

5. Brak odpowiednich szkoleń. W procesie wdrażania BPR należy zmienić większość funkcji i zadań pracowników. W związku z tym pracownik musi zdobyć nowe umiejętności.

6. Odporność na zmiany struktury organizacyjnej oraz kultury organizacyjnej.

W przypadku organizacji publicznych można wyróżnić sześć grup czynników kluczowych we wdrożeniu BPR [Caudle 1995 za: Steiss 2003, s. 144]:

1. Zrozumieć istotę procesu. Posiadanie wiedzy dotyczącej reengineeringu. Wprowadzać zróżnicowane metody doskonalenia procesów. 
2. Budowanie organizacji i kapitału politycznego. Zaangażowanie organizacyjne i zdolności do inicjowania, podtrzymywania reorganizacji. Posiadanie politycznego poparcia dla usprawniania procesów.

3. Przyjęcie orientacji zarządzania procesowego. Ustawienie misji i celów strategicznych pod procesy. Doskonalenie procesów zarządzania poprzez osobistą odpowiedzialność, zaangażowanie i podejmowanie decyzji. Dostosowania struktur organizacyjnych.

4. Ciągły pomiar i śledzenie wyników.

5. Opracowanie strategii zarządzania zasobami ludzkimi w celu wspierania reorganizacji. Budowanie zasobów informacyjnych strategii zarządzania i technologii.

6. Zarządzanie projektem BPR. Określenie kryteriów, co powinno być udoskonalone. Umieszczenie projektu na odpowiednim poziomie z określonym celem reengineeringu i celami zespołu. Wykorzystanie dobrze wyszkolonych i zróżnicowanych zespołów ekspertów.

Istotnym obszarem różniącym podejście do wdrażania BPR w analizowanych organizacjach jest oczekiwanie, co do efektów jego zastosowania. Wydawałoby się, że we wszystkich organizacjach powinny one być one podobne, czyli takie jakie zostały zidentyfikowane w przypadku organizacji biznesowych. Zalicza się do nich zwiększenie wartości organizacji, uzyskanie pozycji lidera na rynku oraz zmniejszenie kosztów.

Tabela 2. Różnice pomiędzy organizacją publiczną a biznesową w kontekście wdrażania BPR

\begin{tabular}{|l|l|l|l|}
\hline \multicolumn{1}{|c|}{ Wymiary } & \multicolumn{1}{|c|}{$\begin{array}{c}\text { Organizacje } \\
\text { biznesowe }\end{array}$} & \multicolumn{1}{c|}{$\begin{array}{c}\text { Organizacje } \\
\text { publiczne }\end{array}$} & \multicolumn{1}{c|}{$\begin{array}{c}\text { Implikacje } \\
\text { do wdrożenia BPR }\end{array}$} \\
\hline i zamierzenia & $\begin{array}{l}\text { Dążenie do wzrostu } \\
\text { zysku i biznesu. } \\
\text { Dostosowane IT } \\
\text { i strategii bizneso- } \\
\text { wej. }\end{array}$ & $\begin{array}{l}\text { Wykonanie prawa } \\
\text { i polityki } \\
\text { Stabilność i niechęć } \\
\text { do ryzyka } \\
\text { Kontrolowanie zgod- } \\
\text { ności z prawem }\end{array}$ & $\begin{array}{l}\text { Radykalne zmiany często } \\
\text { niewykonalne } \\
\text { BPR musi zostać zwe- } \\
\text { ryfikowane pod kątem } \\
\text { zgodności prawnej }\end{array}$ \\
\hline Procesy & $\begin{array}{l}\text { Proces inicjowany } \\
\text { przez klienta. } \\
\text { Relacje z klientem, } \\
\text { dostawcą. } \\
\text { Pełna kontrola nad } \\
\text { strukturę procesu. }\end{array}$ & $\begin{array}{l}\text { Procesy oparte na } \\
\text { przepisach prawa. } \\
\text { Mała kontrola struk- } \\
\text { tury procesu. }\end{array}$ & $\begin{array}{l}\text { BPR jako odgórne } \\
\text { procesy. } \\
\text { Radykalne zmiany często } \\
\text { niewykonalne } \\
\text { BPR musi zostać zwe- } \\
\text { ryfikowane pod kątem } \\
\text { zgodności z prawem }\end{array}$ \\
\hline
\end{tabular}


Cd. tab. 2

\begin{tabular}{|c|c|c|c|}
\hline Wymiary & $\begin{array}{l}\text { Organizacje } \\
\text { biznesowe }\end{array}$ & $\begin{array}{l}\text { Organizacje } \\
\text { publiczne }\end{array}$ & $\begin{array}{c}\text { Implikacje } \\
\text { do wdrożenia BPR }\end{array}$ \\
\hline $\begin{array}{l}\text { Struktura } \\
\text { organizacyjna }\end{array}$ & $\begin{array}{l}\text { Wielkości i rodzaje } \\
\text { struktur zróżnico- } \\
\text { wane i elastyczne. } \\
\text { Różne poziomy } \\
\text { autonomii władzy. }\end{array}$ & $\begin{array}{l}\text { Obowiązkowe zada- } \\
\text { nia i obowiązki. } \\
\text { Zarządzanie pod } \\
\text { presją polityczną } \\
\text { Sztywne struktury } \\
\text { hierarchiczne. }\end{array}$ & $\begin{array}{l}\text { Formalny proces decy- } \\
\text { zyjny. } \\
\text { Wsparcie z góry na dół. } \\
\text { Potrzeba akceptacji przez } \\
\text { wszystkie zainteresowa- } \\
\text { ne strony. } \\
\text { Zaangażowanie eksper- } \\
\text { tów wewnętrznych. } \\
\text { Niewystarczająca wymia- } \\
\text { na informacji pomiędzy } \\
\text { instytucjami projektów } \\
\text { BPR. } \\
\text { Duży potencjał między } \\
\text { instytucjonalnej platfor- } \\
\text { my zarządzania wiedzą. }\end{array}$ \\
\hline $\begin{array}{l}\text { Wykonalność } \\
\text { ekonomiczna }\end{array}$ & $\begin{array}{l}\text { Wolność w alokacji } \\
\text { środków i kontroli } \\
\text { inwestycji. } \\
\text { Odpowiedzialność } \\
\text { wobec właścicieli. } \\
\text { Motywacja do mini- } \\
\text { malizacji kosztów. }\end{array}$ & $\begin{array}{l}\text { Ograniczenia fiskal- } \\
\text { ne.- Wstępnie zdefi- } \\
\text { niowane zasoby. } \\
\text { Pozwolenia rządowe } \\
\text { Kontrola publiczna. } \\
\text { Motywacja do } \\
\text { utrzymania kosztów } \\
\text { w budżecie (funkcje } \\
\text { budżetu jako warto- } \\
\text { ści progowej). }\end{array}$ & $\begin{array}{l}\text { Sztywne budżety finan- } \\
\text { sowe. } \\
\text { Zasoby (know-how, } \\
\text { IT itd.) wydają się być } \\
\text { ograniczone. }\end{array}$ \\
\hline $\begin{array}{l}\text { Wykonalność } \\
\text { polityczna }\end{array}$ & $\begin{array}{l}\text { Brak zależności. } \\
\text { Finansowanie } \\
\text { wewnętrzne. }\end{array}$ & $\begin{array}{l}\text { Surowe ograni- } \\
\text { czenia rządowe } \\
\text { i polityczne. Zmiany } \\
\text { przepisów i wytycz- } \\
\text { nych }\end{array}$ & $\begin{array}{l}\text { Proponowane zmiany } \\
\text { mogą napotkać opór } \\
\text { przez decydentów i inne } \\
\text { zainteresowane strony. } \\
\text { Wykonalność polityczna } \\
\text { powinna być zapewniona } \\
\text { na początku procesu. }\end{array}$ \\
\hline
\end{tabular}

Źródło: opracowanie własne na podstawie M.C. Jurisch, Ch. Ikas, W. Palka, P. Wolf, H. Krcmar, A Review of Success Factors and Challenges of Public Sector BPR Implementations, Proceedings of the 45th Hawaii International Conference on System Sciences 2012, p. 2608.

W przypadku organizacji publicznych zwraca się uwagę na efektywne wykorzystanie zasobów, ujednolicenia i automatyzację procedur, zmniej- 
szenie kosztów biurokracji oraz poprawę dostępności usług i ich użyteczność dla obywateli. Jednym wspólnym obszarem oczekiwań w obu typach organizacji jest zmniejszenie kosztów funkcjonowania. Należy jeszcze zwrócić uwagę na aspekt związany z czasem realizacji danych zadań. W podejściu biznesowym oczekuje się jego skrócenia, podobnie powinno być w organizacjach publicznych, jednak w tym przypadku często występują ograniczenia natury prawnej np. kodeks postępowania administracyjnego.

\section{PODSUMOWANIE}

Koncepcja wprowadzania zmian w organizacjach publicznych i biznesowych oparta na BPR w podstawowych wymiarach nie różni się znacznie. Różnice występuję w przypadku, gdy analizie poddamy wpływ otoczenia na ich funkcjonowanie. Podstawowa różnica w tym obszarze wynika z wpływu polityki na zarządzanie organizacjami publicznymi. Powoduje to brak stabilności zatrudnienia naczelnego kierownictwa, a co z tego wynika to brak zaangażowania we wprowadzaniu radykalnych zmian w swoich organizacjach. Drugim czynnikiem jest silne powiązanie pomiędzy wykonywanymi zadaniami przez organizacje publiczne a przepisami prawa i wynikającymi z nich procedurami. Istotna różnica wynika również $\mathrm{z}$ faktu, że w przypadku organizacji publicznych nie zawsze najważniejsza jest perspektywa klienta w optymalizacji procesów. Nie znaczy to, że ta perspektywa nie ma znaczenia w funkcjonowaniu organizacji publicznych, lecz bardzo często nie stanowi głównego zainteresowania ze strony decydentów.

\section{LITERATURA}

Brilman J., Nowoczesne koncepcje i metody zarządzania, PWE, Warszawa 2002.

Caudle S. L., Reengineering for Results: Keys to Success from Government Experience, National Academy of Public Administration, Washington 1995.

Christensen T., P. Lægreid, P.G.Roness, K.A. Røvik, Organization Theory and the Public Sector Instrument, culture and myth, Routledge Taylor \& Francis, London-New York 2007.

Gabryelczyk R., Reengineering. Restrukturyzacja Procesowa Przedsiębiorstwa, Studia Informatyki Gospodarczej, Uniwersytet Warszawski, Warszawa 2000.

Grajewski P., Organizacja procesowa, PWE, Warszawa 2007. 
Habib M.N., Understanding Critical Success and Failure Factors of Business Process Reengineering, „International Review of Management and Business Research" 2013, Vol. 2, Issue 1.

Hammer M., Champy, J., Reengineering the Corporation, Harper Business, New York 1993.

Hammera H., J. Champy, Reengineering w przedsiębiorstwie, Key Text. Warszawa.

Herzog, N.V., Polajnar, A., Tonchia, S., Development and validation of business process reengineering (BPR) variables: a survey research in Slovenian companies. ,International Journal of Production Research” 2007, nr 45 (24).

Jurisch M.C., Ikas Ch., Palka W., Wolf P., Krcmar H., A Review of Success Factors and Challenges of Public Sector BPR Implementations, Proceedings of the 45th Hawaii International Conference on System Sciences 2012.

Kisielnicki J., MIS - systemy informatyczne zarządzania, Placet, Warszawa 2008.

Kożuch B., Zarys rozwoju zarządzania publicznego, „Współczesne Zarządzanie” 2006, nr 3.

McAdam, R., O'Hare, C., An improved BPR approach for offline enabling processes: A case study on a maintaining process within the chemical industry, „Business Process Management Journal” 1998, nr 4 (3).

Oliński M., Reengineering, w: Mioduszewski J., Metody organizacji i zarządzania, Wydawca Expol, Olsztyn 2013.

Pszczołkowski T., Mała encyklopedia prakseologii i teorii organizacji, Ossolineum, Wrocław-Warszawa-Kraków-Gdańsk 1978.

Rainey H.G., Understanding and Managing Public Organizations, John Wiley \& Sons, San Francisco 2009.

Rainey H.G., Backoff R W., Levine Ch. H., Comparing Public and Private Organizations. „Public Administration Review” 1976, Vol. 36, Nr 2.

Steiss A.W., Strategic Management for Public and Nonprofit Organizations, Marcel Dekker Inc., New York 2003.

\title{
DIFFERENCES IN IMPLEMENTING BUSINESS PROCESS REENGINEERING IN PUBLIC AND BUSINESS ORGANISATIONS
}

\begin{abstract}
The process approach in management is used both in business and public organisations. Development of interest in process-based concepts as an instrument improving organisational effectiveness resulted from criticism of the functional approach in organisations. The article presents the concept of Business Process Re-
\end{abstract}


engineering (BPR). The purpose of this study is to determine the differences in the implementation of BPR concept in public and business organisations and to identify the key factors in its implementation. An important area of distinguishing the approaches of implementing BPR in the analysed organisations is the expectation as to the outcome of its application, the importance of environmental influences and different approaches to the meaning of the recipient of services.

Keywords: Business Process Reengineering; public organisation; business organization. 